\title{
The challenge of career guidance and counseling during the covid-19 pandemic
}

\author{
Dhanang Suwidagdho ${ }^{1}$, Suci Prasila Dewi ${ }^{2}$ \\ Universitas Mercu Buana Yogyakarta ${ }^{1}$, Universitas Negeri Yogyakarta ${ }^{2}$ \\ dhanang@mercubuana-yogya.ac.id
}

Submitted : 2020-09-13, Revised : 2020-11-04, Accepted : 2020-11-24

\begin{abstract}
The Covid-19 pandemic has also opened up opportunities on how career guidance services build roles in the wider community. Whereas in the world of work, globally everything has stopped, projects have been postponed, and workplaces have been closed indefinitely. This journal is a literature review that discusses career guidance and counseling services that are very important in an effort to help victims of layoffs that have occurred as well as workers in general. This problem can be solved through the career guidance function as a treatment to help individuals overcome career-related problems. The essence of the function of career guidance as a stimulus is the ability to anticipate all future possibilities and achieve career maturity. In the future, workers mindsets need to be changed through career guidance services in the form of knowledge assistance on how to manage finances. Through providing career guidance services as a form of treatment and stimulus, individuals will have selfmotivation to rise from adversity and get new jobs that match their interests and expertise, find another source of income and to build passive income.
\end{abstract}

Keywords: Career Guidance; Covid-19; Layoffs

\section{Introduction}

The Covid-19 pandemic has caused chaos in the world system, the worst in human history. Billions of people have been affected by the Covid-19 pandemic in various sectors. In the world of education, the United Nations reports that Covid-19 has made at least 1.6 billion students in more than 190 countries on every continent unable to carry out educational activities as usual because schools are closed and at least $94 \%$ of other learning spaces must be closed due to the pandemic (UNSDG, 2020). Whereas in the world of work, globally everything has stopped, projects have been postponed, and workplaces have been closed indefinitely. Workers who are still working have to adjust to keep their distance from working from home (Bick et al., 2020; Monitor, 2020). As a result, the world economy is slowing down, and economic recession in all countries without exception due to the influence of the novel coronavirus.

In Indonesia, the total number of formal and informal workers affected by Covid-19 has reached more than 3.5 million people. Meanwhile, data that has been verified by the Ministry of Manpower through BPJS Ketenagakerjaan has reached 2,146,667 people. The verified data consisted of 1,132,117 formal workers who were sent home, while 383,645 workers were laid off. The affected informal sector workers reached 630,905 people (Kemnaker, 2020). The alarming numbers of a virus that was initially labeled as just an ordinary "flu."

Similar findings from the results of research conducted by LIPI, Covid-19 caused a wave of layoffs of workers and decreased income as a result of disruption of business activities in most sectors. As many as 15.6 percent of workers experienced layoffs and $40 \%$ of workers experienced a decrease in income, of which 7 percent of labor income fell to $50 \%$ (Cahyani, 2020). This cannot be separated from the decline in people's purchasing power, which causes the income of entrepreneurs and industry to decline. To reduce the amount of costs incurred, companies like it or not, take a number of steps. For example, by laying off employees, giving unpaid leave or being sent home temporarily.

Individuals who experience layoffs will experience very tough times in their lives. The results of the study prove that job loss has a direct effect on a person's mental state, such as 
symptoms of low job satisfaction, depression, low self-esteem, unhappiness, and even suicide (Doiron \& Mendolia, 2012). This condition arises not only because of decreased income, but there are other things that arise because work is not the only source of income, but also provides social interaction, provides a good identity in society, and affects the self-confidence of victims.

Career Guidance and Counseling Services are very important in an effort to help victims of layoffs that have occurred as well as workers in general. Career Guidance Service that was born in America and has been developed since 1908 by Frank Parson, includes various activities organized by professionals in the field of guidance and counseling to help individuals overcome career-related problems (Savickas, 2019). These problems include exploring career options that exist in the world of work, finding jobs that match your interests and character, doing career planning for all scenarios.

Layoffs are only one scenario that concerns career guidance. This condition needs serious attention and treatment from experts so that individuals can immediately change their mindset to be more positive and rise from adversity. The covid-19 pandemic has also opened up opportunities on how career guidance services build roles in the wider community.

\section{Layoffs, are they so terrible?}

It is undeniable that layoffs are a common practice in the business world which will have an impact on those who lose their jobs. Layoffs will have an impact on health problems due to stress and financial strains (Michaud et al., 2016). These impacts will usually appear immediately after layoffs occur and loss of income is an immediate impact, although not necessarily the worst stressor. The loss of income may not be felt at first due to severance pay and the availability of savings, so that the impact will only be felt in the next few months. Other stressors that arise after an individual is laid off are disconnection from co-workers, loss of social status, triggering a small proportion of post power syndrome, and other things.

The level of stress in each individual certainly varies depending on the mindset of each individual. The break-up of work relations is a big problem for individuals who have a "person" career orientation in the career concept of Anne Roe, who urgently needs interaction with other individuals. Meanwhile, individuals with "non-person" career patterns will not be too affected by this because their personality patterns in choosing jobs that do not really require close relationships with colleagues (Herr \& Cramer, 1988). The postulate of the loss of social status and the emergence of post power syndrome will occur in individuals with high self-esteem because of the enormous need for recognition from others.

Workers who experience layoffs have different conditions with workers who resign from their jobs due to the time availability factor. Resignation from work usually has been carefully prepared by an individual, thought about its positive and negative impacts and has prepared future plans. Meanwhile, layoffs are usually carried out suddenly, although in some cases there have been rumors of layoffs since long ago, so that individuals are usually not ready to face such sudden changes in conditions. Layoffs are also more identified with things that cannot be controlled by workers and are usually unwanted, unlike resignation.

The things above are triggers for stress and anxiety that may arise in workers who experience layoffs. However, it must also be noted that layoffs not only make the individuals who experienced them become stressed and experience a downturn, but they can also cause stress to the remaining staff who "survived" the layoffs. Negative and excessive thoughts will fill the workers, creating pressure that leads to decreased productivity. 


\section{Career Guidance Strategy during the Covid-19 Pandemic}

Vocational guidance was originally designed by Frank Parson through the Boston Vocation Bureau to help young people make career decisions and find the right job in the period after completing education. This success is important because high expectations from the environment and from within sometimes cause stress in the individual.

Through career guidance, individuals will be provided with assistance to understand the ins and outs of the world of work in more depth, the factors that influence, the opportunities that exist and how to get a job that matches their interests and talents. In fact, not infrequently, counselors will describe unpaid jobs as a place to gain work experience (Kapur, 2018). This work experience is important because it is not uncommon for a job position to require work experience in a similar field as a prerequisite for applying for the job.

In the context of the Covid-19 pandemic, there are several issues of concern in the dynamics of the world of work. The inevitable layoffs in various sectors of work require the role of professional counselor through career guidance services to reduce tension and anxiety that arise. This problem can be solved through the career guidance function as a treatment to help individuals overcome career-related problems. Career guidance services are provided so that individuals are able to make career decisions, overcome doubts about the work that has been chosen, prevent hasty and unwise job choices, and help find matches between interests and talents and jobs that suit both of these (Herr \& Cramer, 1988; Whiteley \& Resnikoff, 1978).

If treatment is more problem oriented, career guidance can also be seen as a stimulus oriented which is more knowledge and expertise acquisition. Career guidance not only helps individuals to explore opportunities that exist in the world of work, but also analyzes individual skills, skills, qualifications, and past experiences so that counselors can help provide direction in a more appropriate direction (Jain, 2017; Kapur, 2018; Stăiculescu et al., 2017). Finding individual interests and what occupations match those interests can be done by counselors such as using the RIASEC concept from Holland (D. Brown, 2002; S. D. Brown \& Lent, 2004). The essence of the function of career guidance as a stimulus is the ability to anticipate all future possibilities and achieve career maturity (Won, 2019). Through providing career guidance services as a form of treatment and stimulus, individuals will have self motivation to rise from adversity and get new jobs that match their interests and expertise. An overview of the relationship between these things can be seen in the following chart:

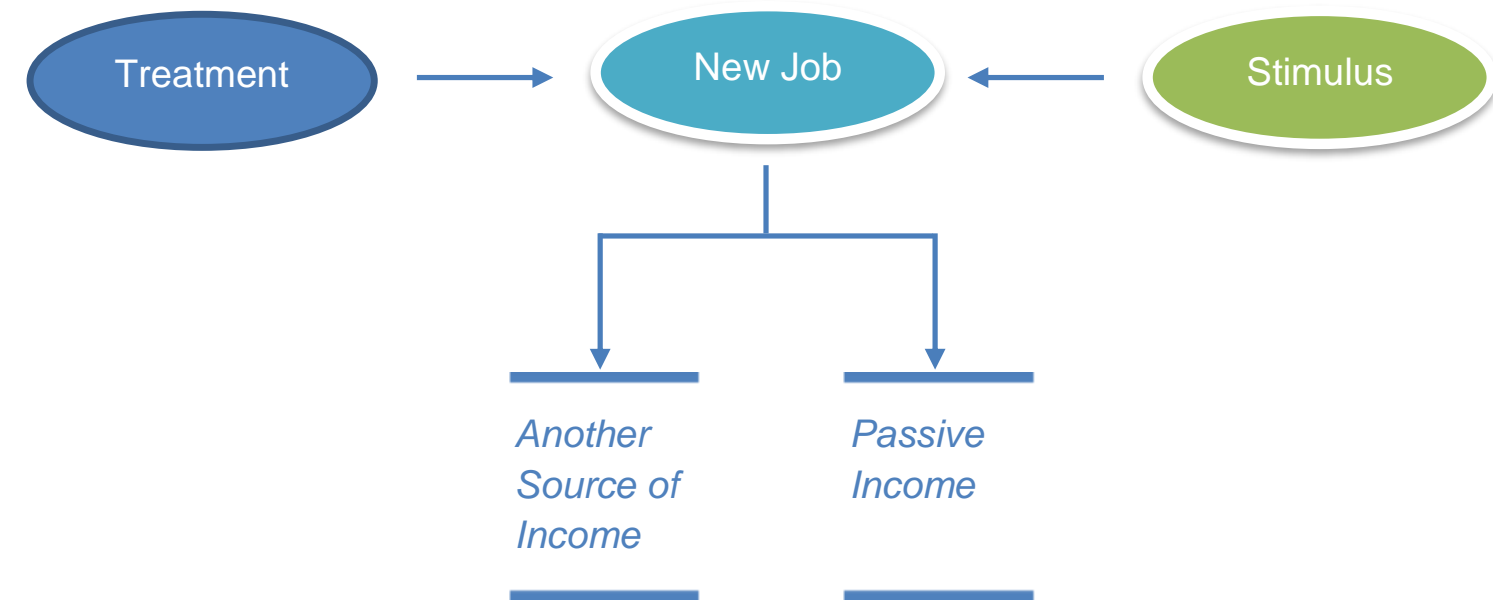

Figure 1. Relationship Model 
The fact that the situation has changed so drastically has opened up opportunities for new mindsets for workers in Indonesia. Shocks that occur due to job loss and loss of income need to be anticipated through the willingness of individuals to have other sources of income outside the main job and the ability to build passive income. Having another source of income can be used as "plan B" when the main job is to be rocked by layoffs. Through this, it is hoped that the impact caused by the loss of main income will be insignificant, supported by additional work. The form doesn't have to always look for additional work, but can also build your own business starting from a small or medium business.

In the future, workers mindsets need to be changed through career guidance services in the form of knowledge assistance on how to manage finances. The income obtained from the main job is allocated to build passive income. Passive income or passive income is the income that a person can get for the economic activities he does without the need to play an active role in these activities. Passive income is the income that a person can generate even while the person is asleep. There are various forms of investment that can be made to build passive income which can be recommended by trained counselors in career guidance such as real estate, and many more (Rattanaprichavej \& Teeramungcalanon, 2020). The combination of the above needs to be built from an early age in workers so that the bitter experiences during the Covid19 pandemic do not repeat themselves in the future with the right preparation and strategy.

\section{Conclusions}

The Covid-19 pandemic has indeed brought more negative impacts in everyday life. Starting from the closure of schools, places of business, economic recession to layoffs. However, through proper career guidance services provided by professional counselors, we can find a positive impact on workers. Providing treatment for individuals who experience layoffs to reduce stress and rise from adversity as well as providing stimulus so that individuals understand their past skills, skills, qualifications, and experiences in order to get a new job. A new mindset also needs to be built so that it does not only rely on one source of income and to build passive income.

\section{References}

Bick, A., Blandin, A., \& Mertens, K. (2020). Work from home after the covid-19 outbreak. Federal Reserve Bank of Dallas, Working Papers, $2020 \quad$ (2017). https://doi.org/10.24149/wp2017

Brown, D. (2002). Career choice and development. John Wiley \& Sons.

Brown, S. D., \& Lent, R. W. (2004). Career development and counseling: Putting theory and research to work. John Wiley \& Sons.

Cahyani, D. (2020). Dampak corona, 3,05 juta orang terkena PHK hingga juni.

Doiron, D., \& Mendolia, S. (2012). The impact of job loss on family dissolution. Journal of Population Economics, 25(1), 367-398. https://doi.org/10.1007/s00148-010-0353-5

Herr, E. L., \& Cramer, S. H. (1988). Career guidance and counseling through the life span: Systematic approaches. Scott, Foresman \& Co.

Jain, P. (2017). Impact of career guidance and counseling on student's career development. Engineer, 17, 83. https://doi.org/10.5281/zenodo.805895

Kapur, R. (2018). Career guidance and student counselling.

Kemnaker. (2020). Menaker Ida: jawa barat, provinsi paling banyak pekerjanya yang terdampak Covid-19. 
Michaud, P.-C., Crimmins, E. M., \& Hurd, M. D. (2016). The effect of job loss on health: Evidence from biomarkers. Labour Economics, 41, 194-203. https://doi.org/10.1016/j.labeco.2016.05.014

Monitor, I. L. O. (2020). COVID-19 and the world of work. Updated Estimates and Analysis.

Rattanaprichavej, N., \& Teeramungcalanon, M. (2020). An investment decision: Expected and earned yields for passive income real estate investors. Cogent Business \& Management, 7(1), 1786331. https://doi.org/10.1080/23311975.2020.1786331

Savickas, M. (2019). Career counseling. American Psychological Association Washington, DC.

Stăiculescu, C., Livinți, R., Ștefan, L. R., Todea, S., \& Albu, N. (2017). Managing the need for career guidance and counseling for students case study-The Bucharest University of Economics Studies. Revista De Management Comparat International, 18(2), 158.

UNSDG. (2020). Policy brief: education during covid-19 and beyond.

Whiteley, J. M., \& Resnikoff, A. (1978). Career counseling. Brooks-Cole Publishing Company.

Won, J. Y. (2019). Effects of family income and career guidance and counseling experience on adolescents' career maturity. The Journal of the Korea Contents Association, 19(2), 638649. https://doi.org/10.5392/JKCA.2019.19.02.638 